\title{
Hvad jeg skrev, det skrev jeg
}

\author{
ANDERS KLOSTERGAARD PETERSEN
}

Carsten Breengaard (CB) har i forlængelse af min anmeldelse af hans bog Paradissekten (RvT 51) skrevet en replik, som jeg godt vil forholde mig til. Diskussion af faglige emner er en god ting. CB gør opmærksom på, at jeg i anmeldelsen giver udtryk for, at jeg både har haft fornøjelse af at læse hans bog og deler mange af dens synspunkter. Derfor vil han afstå fra at drøfte faglige uenigheder eller pointer, som jeg synes at have læst for hurtigt henover. Det turde være tom kritik, som jeg er ude af stand til at forholde mig til; men det får være, hvad det er. CB ønsker med sin replik at præcisere sin tilsigtede læserkreds. Det er fint, da jeg i min anmeldelse netop hævdede, at bogen i den sammenhæng er uklar, og at det just var heri, en af dens største mangler lå. Den er ikke tynget af en traditionel videnskabelig form, men er skrevet essayistisk i et generelt velformuleret og let forståeligt sprog. Omvendt kommer den til kort som formidling, fordi den en række steder er skrevet indforstået til fagfæller i det religionshistoriske og eksegetiske formskærerlaug, og subsidiært ikke føler sig forpligtet på at skulle aflægge regnskab til den etablerede forskning. Er det en modsætning? Det mener i al fald CB, som med reference til to anmeldelser i gymnasiale fagblade gør opmærksom på, at andre har taget bogen til sig som glimrende formidling og har lært af den. Det kan jeg kun bifalde, men må dog, inden begejstringen når uoverstigelige højder, påpege, at det måske også siger noget om hvor, hvornår og af hvem de pågældende anmeldere er uddannet. Dertil kommer, at bøgers kvalitet trods alt (endnu ikke) afgøres ved afstemning.

Hvad jeg skrev, det skrev jeg. Det er en god og læseværdig bog, men den placerer sig mellem forskellige stole, som gør det uklart, hvem den henvender sig til. Og så til det mere saglige. Jeg deler ikke opfattelsen af en uoverstigelig afstand mellem formidling og videnskab. God videnskab er også glimrende formidling, ligesom fornem formidling er båret af kompetent videnskab. Og just det var pointen, hvilket også fremgik af min lettere karikerede spidning af en udbredt videnskabelig form: mit Fussnoten und Anhang. Det, jeg klandrer CB for, er ikke et stort manglende (tysk) noteapparat. Det er manglende formidling af centrale oplysninger. Når han hævder, at den forståelse af tidlig kristendom, han er nået frem til, og som er bogens bærende ide, repræsenterer et videnskabeligt nybrud og er ham selv (teologisk) fremmed, burde han 
have gjort opmærksom på tre ting. For det første og mere personligt (CB har selv bragt det biografiske på bane), at den dialektisk-teologiske tradition, han er rundet af, trods dens dominans i en lang periode af det 20. årh.s nytestamenteforskning blot er en parentes. For det andet, at det synspunkt bogen fremfører som bærende og revolutionerende nyt, var alment tankegods i perioden 1888-1917 (fra Gunkels nytestamentlige licentiatafhandling til Den Religionshistoriske Skoles svanesang med Reitzensteins Die hellenistischen Mysteriereligionen, og i særdeleshed Paul Wernles 1897-afhandling, Christ und die Sünde bei Paulus). At anmeldere i gymnasiale fagblade ikke ved det, siger noget om forskningshistorisk tragik og senere traditioners kolonisering af tidligere; men jeg kan dårligt tro, at CB er uvidende om det. Netop derfor burde han have gjort opmærksom på det. For det tredje og endelig: Når man nu siden begyndelsen af 1980erne internationalt har talt om den nye Paulusforståelse, og der også på dansk har været en heftig debat om emnet, ja at der ligefrem på Gyldendal er udkommet en formidlende bog om sagen, så havde det måske været rimeligt, om CB gjorde sine læsere opmærksom på det. Så meget desto mere, fordi CBs tanker på afgørende punkter nærmer sig hovedideer i den nye Paulusforståelse. Det havde ikke krævet et stort noteapparat, men kunne med fordel være indarbejdet i teksten som al god formidling. Og det var min pointe.

Og så til sidst et lidet hjertesuk. Jeg gjorde i anmeldelsen spagfærdigt opmærksom på, at CB med fordel kunne have draget nytte af sammenligninger mellem tidlig kristendom og nyreligiøse bevægelser i nyere tid. Det tror jeg faktisk, man kan blive klogere af. Hertil får jeg at vide, at “i mit københavnske miljø har nyreligiøsitetseksperterne aldrig formået at bidrage med andet end nedladende kristendomskritik og en anvendelse af kildematerialet som illustration for forudfattede mere eller mindre fikse ideer." Det tror jeg gerne; men der er også en verden uden for Valby Bakke. Og i den verden giver det god mening at sammenligne sekterisme i tidlig kristendom med senere fænomener. Det var sådanne tanker, der lå bag den kritik, jeg fremførte mod en bog, som jeg in toto var og er begejstret for. 